\title{
HUBUNGAN KEKERABATAN BAHASA BATAK MANDAILING DAN BAHASA TANAH ULU (SUATU KAJIAN LINGUISTIK HISTORIS KOMPARATIF)
}

\author{
Family Relationship Of Batak Mandailing and Tanah Ulu Language (A \\ Historic Comparative Linguistic Study)
}

\author{
Sri Riska Dalimunthe \\ Pascasarjana Linguistik FIB USU \\ Pos-el: riskadalimunthe75@gmail.com \\ Tanggal naskah masuk 12 Juni 2018 \\ Tanggal akhir penyuntingan 28 Juni 2018
}

\begin{abstract}
Batak Mandailing and Tanah Ulu languages are two which are spoken on district of Mandailing Natal, Sumatera Utara Province. The Tanah Ulu Language spoken in Muarasipongi and Batak Mandailing spoken in almost entire Mandailing Natal District. The Tanah Ulu Speakers understand Batak Mandailing language but Batak Mandailing speaker can not speak Tanah Ulu language. For this reason, it attempts to analyse how the kinship relationship of the two languages as an Autronesian derivative. The method used is a comparative method with lexicostatistic technique. This technique attempts to compare the two languges and to describe the realationship between the two, both the difference and the equation as well as the kinship level of using 200 Swadesh's basic vocabulary as an analytical material, both lexicon equations were found about $35 \%$ of similarity lexicon. From the number of kinship percentages are gruped that Batak Mandailing and Tanah Ulu languages are families of stock. Next, the computation time of the two languages is compared and the result is 2419. This means that Batak Mandailing and Tanah Ulu languages are related languages and are one of the same languages around 2419 years ago or about 401 BC (calculated from 2018), before finally separating.
\end{abstract}

Keywords: kinship, Batak Mandailing language, Tanah Ulu language, comparative

\begin{abstract}
Abstrak
Bahasa Batak Mandailing dan Bahasa Tanah Ulu adalah dua bahasa yang dituturkan di Kabupaten Mandailing Natal Provinsi Sumatera Utara. Bahasa Tanah Ulu (BTU) khususnya dituturkan di Kecamatan Muarasipongi dan bahasa Batak Mandailing (BBM) umumnya dituturkan di hampir semua wilayah Kabupaten Mandailing Natal. Kecamatan Muarasipongi berbatasan langsung dengan Provinsi Sumatera Barat, jadi BTU dipengaruhi oleh bahasa Minangkabau (bahasa di Provinsi Sumatera Barat). Penutur BTU bisa berbahasa Minangkabau dan BBM, tetapi penutur BBM dan bahasa Minangkabau tidak mengerti BTU. Hal tersebut membuat peneliti menganalisis bagaimana hubungan kekerabatan BBM dan BTU. Seberapa jauh tingkat kekerabatan kedua bahasa tersebut akan dijelaskan melalui teknik perbandingan dan teknik penghitungan waktu pisah kedua bahasa tersebut. Metode yang digunakan adalah metode komparatif dengan teknik leksikostatistik yang berupaya membandingkan kedua bahasa tersebut untuk mendeskripsikan hubungan keduanya. Dengan menggunakan 200 kosakata dasar Swadesh sebagai bahan analisis, ditemukan kesamaan leksikon keduanya sekitar 35\%. Dari jumlah persentase kekerabatan tersebut dikelompokkan bahwa BBM dan BTU adalah keluarga dari satu rumpun. Selanjutnya, dihitung waktu pisah kedua bahasa yang dibandingkan dan hasilnya adalah 2.419. Artinya, BBM dan BTU adalah
\end{abstract}


bahasa yang berkerabat dan merupakan satu bahasa yang sama sekitar 2419 tahun yang lalu atau sekitar tahun 401 Sebelum Masehi (dihitung dari tahun 2018), sebelum akhirnya berpisah.

Kata-kata kunci: kekerabatan, bahasa Batak Mandailing, bahasa Tanah Ulu, komparatif

\section{PENDAHULUAN}

Bahasa mengalamai perubahan dan perkembangan seiring dengan perjalanan waktu. Keraf (1991:34) menyatakan bahwa perubahan dan perkembangan bahasa berbanding lurus dengan penuturnya serta dipengaruhi oleh gerak migrasi penyebaran bahasa-bahasa induk. Bahasa-bahasa yang berasal dari satu induk asal (cognate) memiliki hubungan kekerabatan pada zaman lampau. Hal ini ditunjukkan dengan adanya persamaan bentuk dan makna yang merupakan pantulan dari sejarah warisan yang sama.

Penelitian mengkaji bahasa BBM dan BTU yang termasuk ke dalam rumpun Austronesia atau Melayu Polinesia. Asumsi mengenai kekerabatan kedua bahasa yakni pada kenyataan adanya persamaan dan kemiripan dalam bentuk dan makna. Wilayah penutur kedua bahasa tersebut secara letak geografis berdekatan dan saling berbatasan. Penutur BBM dan BTU berada di Kabupaten Mandailing Natal, Provinsi Sumatera Utara. Penutur BTU tepatnya berada di Kecamatan Muarasipongi, Kabupaten Mandailing Natal yang berbatasan langsung dengan Provinsi Sumatera Barat.

Penutur BTU berada di antara wilayah penutur BBM dengan bahasa Minangkabau, yang berada di Provinsi Sumatera Barat, sehingga para penuturnya bias berbahasa BBM dan bahasa Minangkabau. Sedangkan para penutur BBM dan bahasa Minangkabau tidak mengerti BTU. Hal ini menarik perhatian penulis, untuk meneliti kekerabatan BM dengan BTU. Seberapa jauh tingkat kekerabatan kedua bahasa tersebut akan dijelaskan melalui teknik perbandingan dan teknik penghitungan waktu pisah kedua bahasa tersebut.

\section{LANDASAN TEORI}

Secara teoretis, bahasa-bahasa yang berkerabat memiliki ciri-ciri bentuk dan makna yang sama dalam wujud perangkat kata kerabat (cognate set). Perangkat kata kerabat itu dihipotesiskan berasal dari protobahasa yang sama dan dihipotesiskan juga sebagai cikal bakal bahasa-bahasa itu. Kesamaan dan kemiripan bentuk dan makna itu bukan karena pinjaman dan bukan pula karena kebetulan, melainkan karena meneruskan ciri-ciri asali yang sama (protolanguage). Selain itu, di dalam perangkat kata kerabat itu ersimpan pula kesepadanan bunyi yang teratur pada setiap posisinya. Keteraturan itu oleh kaum neogrammarian disebut sebagai hukum bunyi. Hukum bunyi yang terkenal adalah hukum Grimm dan hukum Verner. Hukum Grimm merupakan hukum kesepadanan bunyi bahasa-bahasa Indo-Eropa, sedangkan dan hukum Verner merupakan hukum kesepadanan bunyi bahasa-bahasa IndoGerman. Hubungan bahasa-bahasa yang berkerabat dalam kajian komparatif, pada prinsipnya dapat dibuktikan berdasarkan unsur warisan dari bahasa induk atau protobahasanya (dalam Widayati, 2018).

Keraf (1991:22) mengatakan bahwa linguistik bandingan historis (linguistik historis komparatif) adalah suatu cabang dari ilmu bahasa yang mempersoalkan bahasa dalam bidang waktu serta perubahan-perubahan unsur bahasa yang terjadi dalam bidang waktu tersebut. Adapun salah satu tujuan dan kepentingan linguistik historis komparatif adalah mengadakan pengelompokkan (sub-grouping) bahasa-bahasa dalam suatu rumpun bahasa. Bahasa-bahasa dalam suatu rumpun yang sama belum tentu sama tingkat kekerabatannya atau sama tingkat kemiripannya satu sama lain. 
Widayati (2014:9) mengatakan bahwa tiap bahasa di dunia memiliki ciri-ciri kesemestaan (universal) tertentu yang mencakup:

1. Tiap bahasa memiliki bentukbentuk tertentu yang dikaitkan dengan maknanya/kesamaan dalam bentuk dan makna.

2. Tiap bahasa memiliki perangkat unit fungsional yang terkecil, yaitu fonem dan morfem.

3. Tiap bahasa memiliki kelas-kelas tertentu, yaitu kata benda, kata kerja, kata sifat, kata ganti orang dan kata bilangan.

Linguistik historis komparatif hanya mempergunakan kesamaan bentuk dan makna sebagai pantulan dari sejarah warisan yang sama. Bahasa berkerabat memperlihatkan kesamaan berikut:

(1) kesamaan sistem bunyi (fonetik) dan susunan bunyi (fonologis);

(2) kesamaan morfologis, yaitu kesamaan dalam bentuk kata dan kesamaan dalam bentuk gramatikal;

(3) kesamaan sintaksis, yaitu kesamaan relasinya antara kata-kata dalam sebuah kalimat.

Pada umumnya bunyi bahasa pertama-tama dibedakan atas vokal dan konsonan. Bunyi vokal dihasilkan dengan pita suara terbuka sedikit dan bunyi konsonan terjadi setelah arus udara melewati pita suara yang terbuka sedikit atau agak lebar, diteruskan ke rongga mulut atau rongga hidung dengan mendapat hambatan di tempat-tempat artikulasi tertentu (Verhaar, 1996:113).

Dalam membandingkan dua bahasa atau lebih dapat menggunakan teknik leksikostatistik. Leksikostatistik adalah suatu teknik untuk menentukan tingkat hubungan di antara dua bahasa dengan menggunakan cara sederhana yaitu membandingkan kosakata yang terdapat pada bahasa yang diperbandingkan kemudian melihat dan menentukan tingkat kesamaan kosakata dari kedua bahasa tersebut (Crowly \& Bowern, 2010; Widayati, 2015). Sedangkan Keraf (1991:121, 128) menyatakan bahwa leksikostatistik adalah suatu teknik dalam pengelompokkan bahasa yang lebih cenderung mengutamakan peneropongan katakata (leksikon) secara statistik, untuk kemudian berusaha menetapkan pengelompokkan itu berdasarkan persentase kesamaan dan perbedaan suatu bahasa dengan bahasa lain. Sebuah pasangan kata akan dinyatakan kerabat bila memenuhi salah satu ketentuan (a) pasangan itu identic, (b) pasangan itu memiliki korespondensi fonemis, (c) kemiripan secara fonetis, atau (d) satu fonem berbeda.

Bahasa yang diperbandingkan dalam leksikostatistik mengacu pada bahasa yang berasal dari protobahasa yang sama tanpa mempertimbangkan seberapa jauh jarak kedua bahasa tersebut. Crowley dan Bowern (2010:139) menyatakan bahwa leksikostatistik memberikan nama spesifik pada level-level pengelompokan yang berbeda, yaitu:

Tabel 1. Kategori Pengelompokan

Bahasa Berdasarkan Persentase

Kekerabatan

\begin{tabular}{|c|l|c|}
\hline No. & \multicolumn{1}{|c|}{$\begin{array}{c}\text { Tingkat } \\
\text { Pengelompokan }\end{array}$} & $\begin{array}{c}\text { Persentase } \\
\text { Kata Kerabat }\end{array}$ \\
\hline 1. & $\begin{array}{l}\text { Dialek dari satu } \\
\text { bahasa }\end{array}$ & $81-100$ \\
\hline 2. & $\begin{array}{l}\text { Bahasa dari satu } \\
\text { keluarga }\end{array}$ & $36-81$ \\
\hline 3. & $\begin{array}{l}\text { Keluarga dari satu } \\
\text { rumpun (stock) }\end{array}$ & $12-36$ \\
\hline 4. & $\begin{array}{l}\text { Turunan dari } \\
\text { sebuah mikropilum }\end{array}$ & $1-4$ \\
\hline 5. & $\begin{array}{l}\text { Mikropila dari } \\
\text { sebuah mesopilum }\end{array}$ & $0-1$ \\
\hline 6. & $\begin{array}{l}\text { Mesopila dari } \\
\text { sebuah makropila }\end{array}$ & \\
\hline
\end{tabular}

Widayati (2015:73-74) menyatakan bahwa persentase kesamaan dan kemiripan 200 kosakata dasar antara bahasa berkerabat kemudian ditabulasikan dan dihitung kemiripannya secara statistik. Untuk menetapkan kata-kata kerabat yang akan diselidiki, ada beberapa prosedur yang harus diikuti, yaitu: 
1. Glos yang tidak diperhitungkan adalah kata-kata kosong, atau slot kosong, yaitu glos yang tidak ada leksikonnya dalam bahasa yang dibandingkan, katakata pinjaman dan kata jadian (bukan kata dasar).

2. Pengisolasian morfem terikat. Datadata yang terkumpul harus diidentifikasikan terlebih dahulu. Bila data tersebut terdiri atas kata jadian yang merupakan hasil bentukan morfem bebas dan terikat, morfem terikatnya harus dipisahkan terlebih dahulu dari kata dasarnya. Hanya kata dasarlah yang bias dibandingkan.

3. Penetapan kata kerabat

a. Pasangan itu identik

b. Pasangan itu memiliki korespondensi fonemis

c. Pasangan itu memiliki kemiripan fonetis

d. Hanya ada satu morfem yang berbeda.

Berdasarkan langkah-langkah tersebut dihitunglah persamaan kata kerabat yang dibandingkan dengan rumus:

$$
\mathrm{c}=\frac{\mathrm{k} \times 100 \%}{\mathrm{n}}
$$

$\mathrm{k}=$ jumlah kata yang berkerabat

$\mathrm{n}=$ jumlah kata yang dibandingkan

Selanjutnya, (dalam Dardanela, 2015:56) dihitung waktu pisah dari bahasa yang diperbandingkan, dengan rumus:

$$
t=\frac{\log c}{2 \log r}
$$

$\mathrm{t}=$ time depth (waktu pisah)

$r=$ retention (daya tahan kosakata).

Menurut Nothofer (dalam Ino: 374) teknik leksikostatistik memiliki beberapa keunggulan bila dibandingkan metodemetode lain. Keunggulan-keunggulan yang dimaksud adalah antara lain,

(1) sebagai daftar kosakata dasar yang cepat dapat menentukan hubungan kekerabatan satu bahasa (bahasa kerabat),

(2) sebagai alat pengelompokan bahasa/ dialek yang sekerabat yang protobahasanya tidak begitu tua/kuno, dan
(3) sebagai alat/metode pengelompokan yang dapat digunakan pada tahap awal untuk menentukan klasifikasi bahasa.

Widayati (2015:77-78) menyatakan bahwa metode penentuan waktu pisah kedua kelompok bahasa tersebut adalah glotokronologi. Glotokronologi adalah suatu teknik dalam linguistik historis komparatif yang berusaha mengelompokkan dua bahasa dengan mengutamakan perhitungan waktu pisah atau perhitungan usia bahasa-bahasa berkerabat.

Kriteria dari penentuan status bahasa yang dibandingkan adalah:

\begin{tabular}{|c|l|c|}
\hline No. & \multicolumn{1}{|c|}{$\begin{array}{c}\text { Tingkat } \\
\text { Pengelompokan }\end{array}$} & $\begin{array}{c}\text { Waktu } \\
\text { Pisah }\end{array}$ \\
\hline 1. & $\begin{array}{l}\text { Dialek dari satu } \\
\text { bahasa }\end{array}$ & $\begin{array}{c}\text { Kurang dari } \\
500 \text { tahun }\end{array}$ \\
\hline 2. & $\begin{array}{l}\text { Bahasa dari satu } \\
\text { keluarga }\end{array}$ & $\begin{array}{c}500-2500 \\
\text { tahun }\end{array}$ \\
\hline 3. & $\begin{array}{l}\text { Keluarga dari satu } \\
\text { rumpun (stock) }\end{array}$ & $\begin{array}{c}\text { 2500-5000 } \\
\text { tahun }\end{array}$ \\
\hline 4. & $\begin{array}{l}\text { Turunan dari } \\
\text { sebuah mikropilum }\end{array}$ & $\begin{array}{c}5000-7500 \\
\text { tahun }\end{array}$ \\
\hline 5. & $\begin{array}{l}\text { Mikropila dari } \\
\text { sebuah mesopilum }\end{array}$ & $\begin{array}{c}7500-10000 \\
\text { tahun }\end{array}$ \\
\hline 6. & $\begin{array}{l}\text { Mesopila dari } \\
\text { sebuah makropila }\end{array}$ & $\begin{array}{c}\text { Lebih dari } \\
10000 \text { tahun }\end{array}$ \\
\hline
\end{tabular}

\section{METODE PENELITIAN}

Pada dasarnya ada dua kegiatan pokok yang dilakukan dalam kajian linguistik historis komparatif, yaitu penentuan hubungan kekerabatan dan rekonstruksi bahasa purba yang menurunkan bahasa-bahasa berkerabat. Untuk penentuan kekerabatan atau pengelompokan bahasa dilakukan dengan dua metode, yaitu metode kuantitatif dan metode kualitatif. Metode kuantitatif memaparkan ihwal metode leksikostatistik, sedangkan untuk metode kualitatif akan dipaparkan ihwal metode kesamaan ciri-ciri linguistik (shared of linguistic features) (Mahsun, 2017:215).

Penelitian ini adalah penelitian kuantitatif dengan metode deskriptif kualitatif menggunakan teknik leksikostatistik dan glotokronologi. Metode 
deskriptif adalah suatu metode yang menggambarkan data secara alamiah, serta menghasilkan kaidah-kaidah kebahasaan secara linguistik. Sedangkan dikatakan kualitatif karena bertujuan membuat deskripsi yang sistematis dan akurat mengenai data yang diteliti berdasarkan fenomena dan fakta empiris yang ada, karena data-data yang dikumpulkan bukanlah angka-angka, namun kata-kata. Metode ini digunakan untuk menghasilkan data deskriptif berupa kata-kata tertulis atau lisan orang-orang dan perilaku yang dapat diamati (Bogdan \& Taylor, dalam Alijah, 2016).

Teknik pengumpulan data yang digunakan dalam penelitian ini adalah teknik:

a. Catat: dalam penelitian ini, teknik catat dilakukan melalui daftar 200 kosakata dasar bahasa Indonesia yang disesuaikan dengan kosakata dasar yang ditemukan oleh Morris Swadesh. Selanjutnya, 200 kosakata ini diterjemahkan oleh para informan ke dalam bahasa daerah masing-masing yang kemudian dicatat langsung oleh peneliti.

b. Rekam: teknik rekam dilakukan terhadap semua kosakata yang diucapkan oleh informan.

Jadi dalam penelitian ini kekerabatan kedua bahasa yaitu BBM, BTU, dan BM akan dijelaskan dan dideskripsikan. Objek diambil dari keseluruhan tuturan yang luas adanya atau tuturan yang sudah diadakan, baik yang dipilih sebagai sampel maupun tidak. Jadi, objek dalam penelitian adalah BBM, BTU, dan BM yang terdapat di wilayah pemakai bahasa masing-masing. Data dalam penelitian ini 200 kosakata Swadesh.

Sesuai dengan permasalahan penelitian ini, yaitu menentukan hubungan kekerabatan BBM, BTU, dan BM, dilakukan dengan berlandaskan teori dalam Linguistik Historis Komparatif.

Analisis data dilakukan dengan metode historis komparatif. BBM, BTU, dan BM dibandingkan secara deskriptif komparatif. Perbandingan secara deskriptif adalah untuk menemukan perubahanperubahan pada bahasa kerabat yang masih digunakan saat ini oleh penuturnya. Perangkat kata kerabat (cognat set) dibandingkan dengan cara memilih bentuk yang berhubungan, karena bentuk yang tidak berhubungan, baik bentuk dan maknanya, diasumsikan berasal dari etimon yang berbeda. Artinya, glos yang tidak diperhitungkan adalah kata-kata pinjaman, kata jadian (bukan kata dasar).

Dari perangkat kata kerabat (cognat set) yang telah dibandingkan tersebut dihitung jumlah bentuk memiliki persamaan dan korespondensi bunyi untuk menetapkan tingkat kekerabatan dan waktu pisah BBM, BTU, dan BM. Bahasa yang diperbandingkan dalam leksikostatistik ini harus mengacu pada bahasa yang berasal dari protobahasa yang sama tanpa mempertimbangkan seberapa jauh jarak kedua bahasa tersebut. Penetapan kata itu berkerabat adalah (1) Pasangan yang dibandingkan itu identik, (2) Pasangan itu memiliki korespondensi fonemis, (3) Hanya ada satu fonem yang berbeda.

Untuk perhitungan leksikostatistik itu digunakan rumus: $\mathrm{C}=\mathrm{k} / \mathrm{n} \times 100 \%$. K adalah kata yang berkerabat dan $\mathrm{n}$ adalah jumlah kata yang dibandingkan. Selanjutnya, dihitung waktu pisah dari bahasa yang dibandingkan, dengan rumus: $\mathrm{t}=\log \mathrm{c} / 2$ $\log \mathrm{r}$. T adalah waktu pisah, $\mathrm{r}$ adalah daya tahan kosakata.

\section{PEMBAHASAN}

Kekerabatan MBM, BTU, dan BM dianalisis berdasarkan pengindentifikasian kedua bahasa tersebut dengan menggunakan kosakata dasar Swadesh, yaitu 200 kosakata dasar. daftar Swadesh dianggap baik dalam penelitian ini karena terdiri atas kata-kata yang nonkultural. Selain itu, retensi kata dasarnya telah teruji dalam bahasa-bahasa yang memiliki naskah tertulis.

Data dari 200 kosakata dasar Swadesh, diidentifikasikan pasangan kata 
kerabat yang dibandingkan melalui pasangan identik. Hasil perbandingan dipaparkan dalam tabel berikut:

Tabel 3. Pasangan yang identik

\begin{tabular}{|c|l|l|l|}
\hline No. & \multicolumn{1}{|c|}{ Glos } & BBM & \multicolumn{1}{|c|}{ BTU } \\
\hline 1. & balik & balik & balik \\
\hline 2. & benih & bibit & bibit \\
\hline 3. & buah & buah & buah \\
\hline 4. & buru & buru & buru \\
\hline 5. & busuk & busuk & busuk \\
\hline 6. & dorong & tulak & tulak \\
\hline 7. & gunung & gunung & gunung \\
\hline 8. & hapus & hapus & hapus \\
\hline 9. & minum & minum & minum \\
\hline 10. & tarik & tarik & tarik \\
\hline 11. & tetek & susu & susu \\
\hline 12. & tumpul & tumpul & usus \\
\hline
\end{tabular}

Dari daftar di atas, diperoleh 12 pasangan yang identik antara BBM dan BT atau sekitar 6\%.

Selanjutnya, kosakata kedua bahasa tersebut diidentifikasikan juga berdasarkan korespondensi fonemis. Pasangan yang memiliki korespondensi fonemis dibedakan atas pasangan berbeda vokal, berbeda konsonan, dan beda satu silabel. Hasil analisis dipaparkan dalam tabel berikut.

Tabel 4. Pasangan berbeda vokal

\begin{tabular}{|c|l|l|l|}
\hline No. & \multicolumn{1}{|c|}{ Glos } & \multicolumn{1}{|c|}{ BBM } & \multicolumn{1}{|c|}{ BTU } \\
\hline 1. & abu & abu & obu \\
\hline 2. & api & api & opi \\
\hline 3. & batu & batu & botu \\
\hline 4. & belah & bola & bəlah \\
\hline 5. & bengkak & beGkak & beGkak \\
\hline 6. & bunga & buGa & buGa \\
\hline 7. & debu & abu & obu \\
\hline 8. & di, pada & di, pada & do \\
\hline 9. & dua & dua & duo \\
\hline 10. & gali & kali & goli \\
\hline 11. & lima & lima & limo \\
\hline 12. & mata & mata & mato \\
\hline 13. & mati & mate & moti \\
\hline 14. & pendek & pondok & pandak \\
\hline 15. & potong & korot & kere? \\
\hline 16. & pusar & pusot & pusək \\
\hline 17. & rambut & obuk & ebuk \\
\hline 18. & tali & tali & toli \\
\hline
\end{tabular}

\begin{tabular}{|l|l|l|l|}
\hline 19. & tangan & taGan & taGin \\
\hline 20. & tidak & inda & ndo \\
\hline 21. & tongkat & tuGkot & tuGkek \\
\hline 22. & sempit & sompit & sempik \\
\hline
\end{tabular}

Dari tabel di atas terdapat hanya 22 data yang berbeda vokal atau sekitar $11 \%$. Perbedaan vokal yang diidentifikasikan antara lain adalah adanya korespondensi a $\simeq$ $\mathrm{o} ; \mathrm{i} \simeq \mathrm{o}, \mathrm{e} \simeq \mathrm{i} ; \mathrm{o} \simeq \mathrm{e}, \mathrm{o} \simeq$ .

Tabel 5. Pasangan berbeda konsonan

\begin{tabular}{|c|l|l|l|}
\hline No. & \multicolumn{1}{|c|}{ Glos } & \multicolumn{1}{c|}{ BBM } & \multicolumn{1}{c|}{ BTU } \\
\hline 1. & binatang & binataG & \\
\hline 2. & bintang & bintaG & bintak \\
\hline 3. & cacing & caciG & cacik \\
\hline 4. & daging & dagiG & dagik \\
\hline 5. & hitung & etoG & etok \\
\hline 6. & jahit & jait & jaik \\
\hline 7. & kata & kecet & kecek \\
\hline 8. & kulit & kulit & kulik \\
\hline 9. & lain & lain & laik \\
\hline 10. & langit & laGit & laGit \\
\hline 11. & tajam & tajom & tajop \\
\hline 12. & tipis & tipis & nipih \\
\hline 13. & sempit & sompit & sempik \\
\hline
\end{tabular}

Pasangan yang berbeda konsonan berjumlah 13 glos atau sekitar 6,5\%. Beda konsonan yang diidentifikasikan adalah adanya variasi konsonan yang dekat artikulasinya, seperti [k] dengan [G] yang sama-sama berciri velar, [j] dengan [k] atau [t] dengan [ $\mathrm{k}]$ yang sama-sama berciri plosif, [m] dengan [p] yang sama-sama berciri bilabial, dan [s] dengan [h] yang sama-sama frikatif (Schane, 1992:xiii).

Sementara yang berbeda satu silabel terdapat pada tabel 6 berikut, yang berjumlah 15 kata atau $7,5 \%$.

Tabel 6. Pasangan berbeda satu silabel

\begin{tabular}{|c|l|l|l|}
\hline No. & \multicolumn{1}{|c|}{ Glos } & \multicolumn{1}{c|}{ BBM } & \multicolumn{1}{c|}{ BTU } \\
\hline 1. & air & aek & ai \\
\hline 2. & anak & daganak & anak \\
\hline 3. & asap & asap & asok \\
\hline 4. & banyak & bahat & banyak \\
\hline 5. & baru & baru & boru \\
\hline 6. & belah & bola & belah \\
\hline 7. & bulan & bulan & bulek \\
\hline 8. & bulu & imbulu & bulu \\
\hline 9. & di sini & dison & dikou \\
\hline
\end{tabular}




\begin{tabular}{|c|l|l|l|}
\hline 10. & ikat & kobet & iket \\
\hline 11. & kita & hita & kito \\
\hline 12. & pusat & pusot & pusek \\
\hline 13. & saya & au & oku \\
\hline 14. & tanah & tano & tanah \\
\hline 15. & ular & ulok & ula \\
\hline
\end{tabular}
psangan yang berbeda satu fonem. Pasangan ini dirinci menjadi (1) beda satu fonem vokal dan (2) beda satu fonem konsonan.

Tabel 7. Pasangan beda satu fonem vokal

\begin{tabular}{|c|l|l|l|}
\hline No. & \multicolumn{1}{|c|}{ Glos } & BBM & \multicolumn{1}{c|}{ BTU } \\
\hline 1. & danau & dano & danou \\
\hline 2. & tidak & inda & ndo \\
\hline
\end{tabular}

Beda satu fonem vokal yang dimaksudkan di sini adalah salah satu bahasa yang dibandingkan memiliki jumlah vokal yang lebih banyak daripada yang lainnya.

Tabel 8. Pasangan beda satu fonem konsonan

\begin{tabular}{|c|l|l|l|}
\hline No. & \multicolumn{1}{|c|}{ Glos } & BBM & \multicolumn{1}{|c|}{ BTU } \\
\hline 1. & bunuh & buno & bunuh \\
\hline 2. & ekor & ikur & iku \\
\hline 3. & kutu & utu & kutu \\
\hline 4. & muntah & muta & muntah \\
\hline 5. & pasir & pasir & pasi \\
\hline 6. & tahu & boto & \\
\hline
\end{tabular}

Berdasarkan tabel di atas terdapat 2 pasangan berbeda vokal atau $1 \%$ dan 6 pasangan berbeda konsonan atau 3\%. Perbedaan satu konsonan umumnya didominasi oleh BTU, meskipun ada juga dalam BTM, yaitu pasir pasi, boto oso. Perbedaan satu fonem vokal dan konsonan ini terdapat pada posisi inisial, dan posisi final. Artinya, bahasa Tanah Ulu memiliki fonem yang lebih panjang daripada bahasa Batak Mandailing.

Keseluruhan kesamaan kosakata dari BTM dan BTU yang dapat disimpulkan dari keenam tabel di atas adalah berjumlah 70 kosakata atau sekitar 35\%. Artinya, persentase kekerabatan keduanya adalah $35 \%$. Persentase ini menunjukkan bahwa BTM dan BTU adalah keluarga dari satu rumpun.
Berdasarkan kesamaan jumlah kosakata tersebut kemudian dihitung waktu pisah keduanya melalui rumus

$$
\begin{gathered}
t=\frac{\log c}{2 \log r} \\
t=\frac{\log 35}{2 \log 805} \\
t=\frac{1050}{2 \times 217} \\
t=\frac{1050}{434} \\
t=2.419
\end{gathered}
$$

Bahasa BBM dan BTU adalah bahasa yang berkerabat dan berpisah sekitar 2.419 tahun yang lalu atau sekitar tahun 401 Sebelum Masehi (dihitung dari tahun 2018). Bahas Nias dan bahasa Sigulai merupakan satu bahasa yang sama sekitar 2419 tahun yang lalu, sebelum akhirnya berpisah.

\section{PENUTUP}

Berdasarkan analisis data dan pembahasan, hasil penelitian ini dapat disimpulkan sebagai berikut.

1. Berdasarkan perhitungan teknik leksikostatistik, dari 200 kosakata bahasa Batak Mandailing dengan bahasa Tanah Ulu terdiri atas 70 kosakata kerabat dan 130 kosakata tidak berkerabat. Jadi, persentase kekerabatan kedua bahasa tersebut adalah 35\%. Hubungan antara bahasa Batak Mandailing dan bahasa Tanah Ulu dapat ditetapkan sebagai bahasa dari keluarga dari satu rumpun.

2. Berdasarkan perhitungan teknik glotokronologi, waktu pisah antara bahasa Batak Mandailing dengan bahasa Tanah Ulu adalah 2.419 tahun yang lalu, terhitung dari tahun 2018 (401 SM).

3. Bukti-bukti korespondensi bunyi antara bahasa Batak Mandailing dengan bahasa Tanah Ulu berdasarkan kosakata Swadesh dapat dilihat dalam beberapa kriteria, 12 kata pasangan identik, 22 
kata pasangan berbeda vokal, 13 kata pasangan berbeda konsonan, 15 kata pasangan berbeda silabel, 2 kata pasangan beda satu fonem, 6 kata pasangan beda satu fonem konsonan.

\section{DAFTAR PUSTAKA}

Alijah, Siti. (2016). Kekerabatan Bahasa Bugis dan Bahasa Muna. Dalam Jurnal Humaniora, 16(1), Maret 2016.

Crowley, Terry dan Claire Boern. (t.t.). An Introduction to Historical Linguistics. Oxford: Oxford University Press.

Dardanela, et al. (2015). Cognates among the Karo, Alas and Gayo Languages. International Journal of Humanities and Social Science, 5(12), December 2015, (55-58).

Ino, La. (2015). Pemanfaatan Linguistik Historis Komparatif dalam Pemetaan Bahasa-bahasa Nusantara. Retorika: Jurnal Ilmu Bahasa, 1(2), Oktober 2015 (365-378).

Keraf, Gorys. (1991). Linguistik Bandingan Historis. Jakarta: Gramedia.
Mahsun. (2017). Metode Penelitian Bahasa, Tahapan, Strategi, Metode dan Tekniknya. Depok: Rajagrafindo Persada.

Maulita, Gokma. (2015). Kekerabatan Bahasa Batak Toba dan Bahasa Batak Angkola Suatu Kajian Linguistik Historis Komparatif. Jurnal Arkhais, 06(1), Januari-Juni 2015.

Schane, Sanford A. Dan Bendixen Birgitte. (1992). Buku Latihan Fonologi Generatif. Jakarta: Summer Institute of Linguistics.

Widayati, Dwi. (2015). Linguistik Historis Komparatif, Buku Ajar, Bahan Ajar. Medan: CV. Mitra Medan.

Widayati, Dwi. (2018). Hubungan Kekerabatan Bahasa Nias dan Bahasa Sigulai. Dalam Jurnal Tutur: Asosiasi Peneliti Bahasa-bahasa Lokal (APBL), 4(1), Februari 2018, 1-8.

Verhaar, JWM. (1996). Asas-asas Linguistik Umum. Yogyakarta: Gadjah Mada University Press. 